\title{
Remediating Cd-Contaminated Soils Using Natural and Chitosan-Introduced Zeolite, Bentonite, and Activated Carbon
}

\author{
Na Yi, Yaoguo Wu*, Lin Fan, Sihai Hu \\ School of Natural and Applied Sciences, Northwestern Polytechnical University, Xi'an, Shaanxi, China
}

Received: 28 December 2017

Accepted: 27 March 2018

\begin{abstract}
The effects of in-situ immobilization of heavy metals by applying natural and chitosan-introduced zeolite, bentonite, and activated carbon (AC) were systematically studied to remediate cadmium (Cd)-contaminated soils in a pot experiment using Brassica juncea as the indicator plant. The results show that zeolite, bentonite, and its chitosan composites can increase soil $\mathrm{pH}$ and reduce the biological effectiveness of heavy metals. The Brassica juncea dry weight increased with increasing of amendment dosage. Highest values were found for CS-AC, followed by CS-bentonite, CS-zeolite, AC, bentonite, and zeolite. With an amendment dosage of $75 \mathrm{~g}$ per pot, Brassica juncea dry weight increased by $41.91 \%$, $39.00 \%, 27.64 \%, 35.93 \%, 23.78 \%$, and $23.58 \%$, respectively, for CS-AC, CS-bentonite, CS-zeolite, AC, bentonite, and zeolite, compared to the control. Cadmium uptake by Brassica juncea was lowest for this dosage. With a dosage of $75 \mathrm{~g}, 50 \mathrm{~g}, 75 \mathrm{~g}, 75 \mathrm{~g}, 50 \mathrm{~g}$, and $75 \mathrm{~g}$ per pot for CS-AC, CS-bentonite, CS-zeolite, AC, bentonite, and zeolite, respectively, Cd uptake decreased by $21.89 \%, 19.88 \%, 19.48 \%$, $18.67 \%, 17.47 \%$, and $13.85 \%$, respectively. Similarly, bioavailable Cd content decreased by $27.38 \%$, $19.29 \%, 22.83 \%, 23.22 \%, 15.74 \%$, and $8.66 \%$, respectively, compared to the control.
\end{abstract}

Keywords: Cd contamination, remediation, chitosan, Brassica juncea, amendments

\section{Introduction}

The heavy metal cadmium (Cd) has long been recognized as a more hazardous pollutant for plants, animals, and humans than any other heavy metal [1-2]. Soil contamination with toxic heavy metals had been a worldwide challenge for food security and health as heavy metals do not degrade, adversely affecting the biota via the food chain [3-6]; therefore,

*e-mail: wuygal@nwpu.edu.cn the accumulation of heavy metals in soil can result in a decrease of soil fertility and soil microbial activities and biodiversity, is collectively responsible for crop losses, and has even more serious implications for animal and human health [7-8]. Studies estimate that the area of soil contaminated with $\mathrm{Cd}$ covers about $1.3 * 10^{5}$ ha and accounts for $1 / 5$ of the total farmland area in China [9]. And more than 11 provinces and 25 districts are subjected to Cd-contaminated soil. In 2007, the direct economic loss from farmland metal pollution reached $\$ 3.2$ billion as calculated by the Ministry of Land and Resource in China [10]. Therefore, the issue of scientific and economic mitigation of Cd-contaminated 
soils requires urgent clarification. Many remediation techniques have been applied for the removal of heavy metals from soils. Chemical methods of soil remediation may destroy soil structure and result in secondary pollution [11]. Therefore, more economic, effective, and environmentally friendly metal chelators are required. The enhancement of chemical immobilization by the addition of soil amendments is increasingly seen as a valuable alternative strategy that can effectively reduce the bioavailability of contaminants [12-13]. Two mechanisms are responsible for the efficiency of this remediation action: 1) the increase in metal sorption of the resulting soil+material mixture and 2) dilution of the contaminant concentration when large material doses are used [14].

A potential "green" metal chelator is chitosan (CS). It is the second most abundant biopolymer in the natural environment and is obtained from the deacetylation of chitin extracted from shellfish processing waste [15-16]. At present, CS is receiving considerable attention as an excellent natural adsorbent to remove numbers of heavy metal ions due to the presence of amine $\left(-\mathrm{NH}_{2}\right)$ and amounts of reactive hydroxyl $(-\mathrm{OH})$ function groups on the main chain, which act as chelation sites for metal ions [15, 17-18]. The largely spread hydroxyl and amine groups serve as effective chelating sites for heavy metals through ion exchange, adsorption, and complexation. Of these, complexation is the major, stable, and irreversible form [19]. Although the adsorption of chitosan on $\mathrm{Cd}^{+}$and other heavy metal ions has been widely studied [20-21], the studies of chitosan on $\mathrm{Cd} 2^{+}$-contaminated soils are too rare.

Clay minerals have larger interior and exteriorspecific surface areas, many reactive functional groups, and the hydration and dehydration of interlaminar surface [22]. The high metal adsorption capacity and low cost of clay minerals makes them one of the most common remediation options for metal adsorption [23-25]. They therefore have an ability to bind heavy metals, preventing their transportation from the soil into the plant. Zeolite is an important clay mineral and has been used in numerous studies on Cd-polluted soils [26-28]. Similarly, bentonite is a type of expandable clay composed primarily of montmorillonite and characterized by high permanent negative charges and a large surface area [29]; it is also an efficient adsorbent for $\mathrm{Cd}[28,30]$. Activated carbon (AC) with large surface area has been used for a long time as an efficient amendment to remediate Cd-contaminated soil; the capability of $\mathrm{AC}$ to bind $\mathrm{Cd}$ has been confirmed by Břendová et al. [31].

Cruciferae canola is a plant with strong absorption characteristics and heavy metal enrichment ability [32]. Brassic juncea is a variety of cruciferae canola. Brassica juncea was selected as the experimental species because of its short life stage, high biomass, and the hyperaccumulation ability of heavy metal [33]. And Brassica juncea, a widely consumed species, is very sensitive to the presence of toxic elements in soil. In addition, the great commercial value of Brassica juncea makes it necessary to protect it from $\mathrm{Cd}$ contamination. It has great potential applications in phytoremediation. Considering ecology, toxicology, and health, it is particularly important to study the contents of effective heavy metals in contaminated soil, because these components are easily magnified through biont. In order to reduce the amount of heavy metals in plants, it will be an effective way to improve the contaminated soil by heavy metals, and adding amendments into the soil reduces the effectiveness of heavy metals. In recent years, extensive research have been conducted on adjusting the soil parameters to reduce the effectiveness of heavy metal through adding a hardening agent (activated carbon, zeolite, bentonite, etc.) into the contaminated soil by heavy metal. The method of heavy metal pollution treatment can be widely applied due to the advantages of economically viable and nondestructive soil structures [34]. In addition to reducing the dissolubility of heavy metals, the amendments can effectively reduce the bioavailability of heavy metals and the negative effects on health [35]. The objective of this study was to evaluate the efficiency of Cd-contaminated soil by natural and chitosan-introduced zeolite, bentonite, and $\mathrm{AC}$ in the remediation of Cd-contaminated soils. We determined the effects of these substances on soil $\mathrm{pH}$, dry weight of individual Brassica juncea, Cd uptake of Brassica juncea, and bioavailable $\mathrm{Cd}$.

\section{Experimental Section}

\section{Soil and Amendments}

Soil (0-20 cm depth) was collected from a greenhouse in Yangling, Shaanxi Province, China. Phosphate was applied to the soil over a period of 30 years. The soil was air-dried, thoroughly mixed, and passed through a $20-\mathrm{mm}$ mesh sieve to remove gravel. The soil was classified as loess soil, and some of the physical and chemical properties were listed in Table 1. The $\mathrm{pH}$ was measured with a $\mathrm{pH}$ meter (FE28-Meter, Mettler Toledo instrument co., LTD, China) in a 1:5 (w/w) soil- $\mathrm{H}_{2} \mathrm{O}$ slurry. Soil organic matter content was determined using the potassium dichromate-outside heating method. Bioavailable $\mathrm{Cd}$ was extracted for $2 \mathrm{~h}$ at room temperature with DTPA (DTPA-TEA$\mathrm{CaCl}_{2}, \mathrm{pH}=7.3$ ) buffer solution. Heavy metal content was determined using a flame atomic absorption spectrophotometer (Z-2000, Hitachi, Japan.).

Zeolite, bentonite, and activated carbon were obtained from the Zhongchuan mineral powder processing plant, Lingshou, Hebei province, China. Industrial-grade chitosan was obtained from Guangzhou Shengxun chemical industry co. LTD, and it had the following properties: yellowish-white powder with 100 meshes, 93\% degree of deacetylation, and a molecular weight of $2 * 10^{6}$. 
Table 1. Physiochemical properties of the $0-20 \mathrm{~cm}$ soil layer in the experimental area. Values represent mean \pm standard deviation $(\mathrm{n}=3)$.

\begin{tabular}{|c|c|c|}
\hline Parameter & Unit & Value \\
\hline Soil type & & Heavy loam \\
\hline $\mathrm{pH}$ & & $7.81 \pm 0.10$ \\
\hline Total nitrogen & $\mathrm{g} \mathrm{kg}^{-1}$ & $1.69 \pm 0.05$ \\
\hline Olsen phosphate & $\mathrm{mg} \mathrm{kg}^{-1}$ & $303.6 \pm 8.47$ \\
\hline Available potassium & $\mathrm{mg} \mathrm{kg}^{-1}$ & $722.7 \pm 14.12$ \\
\hline Soil organic matter & $\mathrm{g} \mathrm{kg}^{-1}$ & $36.15 \pm 1.10$ \\
\hline $\mathrm{Cd}$ & $\mathrm{mg} \mathrm{kg}^{-1}$ & $1.55 \pm 0.04$ \\
\hline Available Cd & $\mathrm{mg} \mathrm{kg}^{-1}$ & $0.29 \pm 0.03$ \\
\hline $\mathrm{Fe}$ & $\%$ & $3.11 \pm 0.21$ \\
\hline $\mathrm{Cu}$ & $\mathrm{mg} \mathrm{kg}^{-1}$ & $24.6 \pm 1.98$ \\
\hline $\mathrm{Zn}$ & $\mathrm{mg} \mathrm{kg}^{-1}$ & $69.5 \pm 3.48$ \\
\hline $\mathrm{Ca}$ & $\%$ & $4.79 \pm 0.22$ \\
\hline $\mathrm{Mg}$ & $\%$ & $1.28 \pm 0.02$ \\
\hline
\end{tabular}

\section{Incubation and Pot Experiments}

Different dosage (25 g, $50 \mathrm{~g}$, and $75 \mathrm{~g}$ ) amendments (zeolite, bentonite, AC) and chitosan-introduced composites (the application ratio of $\mathrm{CS}$ was $6 \%$ in chitosan-introduced composites. CS-zeolite, CS-bentonite, CS-AC) were thoroughly mixed with $5 \mathrm{~kg}$ of Cd-contaminated soil; subsequently, the amended soil and the control soil samples were packed into respective pots. A control treatment with no amendment was also prepared. All soil samples were incubated for one month.

Seeds of Brassica juncea were sowed in the middle of the greenhouse after mixing the unpolluted surface soils using a rotary machine. The cultivation area was covered with polyethylene plastic film to ensure adequate moisture. After three weeks, three equally sized seedlings of Brassica juncea $(10 \mathrm{~cm}$ in height) were transplanted into each pot. Soli water was maintained at $60 \% \mathrm{WHC}$ by adding tap water daily.

\section{Sampling Pretreatment and Metal Analysis}

On July 4, 2015, plant samples were harvested and rinsed with tap water to remove surface soil. The plants were then carefully washed with deionized water and dried of surface water. The fresh samples were weighed and subsequently oven-dried at $105^{\circ} \mathrm{C}$ for $30 \mathrm{~min}$, then at $70^{\circ} \mathrm{C}$ until constant weight. The dried samples were crushed and ground to a fine powder using a highspeed universal pulverizer (FW100, Zhongxing Weiye instrument co., LTD, China) and stored in plastic bags until analysis.

For analysis, $0.5 \mathrm{~g}$ of the dried plant sample was placed into a $100 \mathrm{~mL}$ beaker covered with a funnel. Then $15.0 \mathrm{~mL}$ of solution containing $87 \%$ of concentrated $\mathrm{HNO}_{3}$ and $13 \%$ of concentrated $\mathrm{HClO}_{4}(\mathrm{v} / \mathrm{v})$ was added. The sample was digested at $50-80^{\circ} \mathrm{C}$ overnight and then at $180^{\circ} \mathrm{C}$ for $8 \mathrm{~h}$ to near dryness and allowed to cool. The digested solution was diluted with $2 \%(\mathrm{v} / \mathrm{v}) \mathrm{HNO}_{3}$ to a volume of $25.0 \mathrm{~mL}$ before filtration. The concentration of $\mathrm{Cd}$ in the digested plant sample was determined using a flame atomic absorption spectrometer at a wavelength of $228.8 \mathrm{~nm}$ [36]. Standard material, GBW-10015, was bought from a standard material center in Beijing, China to control analysis quality. The recovery rate was $95 \pm 75 \%$.

\section{Statistical Analysis}

All analyses were performed using SigmaPlot 12.5(Systat Software Inc.), Excel 2000, and Origin 9.0 software. One-way ANOVA and multiple comparisons (Fisher LSD Method) were used to compare the difference in the dry weight of individual Brassica juncea, Cd uptake of Brassica juncea, and bioavailable $\mathrm{Cd}$ content; significance levels were 0.01 and 0.05. Data represent mean values of three replicates.

\section{Results and Discussion}

\section{Effects of Different Amendments on Soil pH}

Soil $\mathrm{pH}$ is an important factor of heavy metal adsorption as it affects the biological effectiveness of heavy metal ions in the soil. The $\mathrm{pH}$ values of different amendments and its chitosan composites are shown in Table 2. All of amendments were alkaline. Table 3 shows the $\mathrm{pH}$ value effect of the soil sample treated with different amendments. It is well known that biological effectiveness of heavy metal ions in soil decreased with increasing soil $\mathrm{pH}$ [37]. And the concentration of heavy metals in soils was influenced by soil $\mathrm{pH}$ [38]. However, some amendments showed nonspecific adsorption. Heavy metal adsorption varied with changing soil $\mathrm{pH}$ values. At low soil $\mathrm{pH}$ we observed competitive adsorption between heavy metals and a high concentration of $\mathrm{H}^{+}$in the soil, impeding heavy metal adsorption [39]. The adsorbed metal ions increased

Table 2. $\mathrm{pH}$ values of different amendments.

\begin{tabular}{|c|c|c|c|c|c|c|c|}
\hline Amendments & CS & Zeolite & Bentonite & AC & CS-Z & CS-B & CS-AC \\
\hline $\mathrm{pH}$ & 7.823 & 7.802 & 8.975 & 10.133 & 8.411 & 9.063 & 9.876 \\
\hline
\end{tabular}


Table 3. $\mathrm{pH}$ value effects of the soil samples treated with different amendments.

\begin{tabular}{|c|c|c|c|c|}
\hline \multirow{2}{*}{ Amendments } & \multicolumn{4}{|c|}{ Added contents of different amendments(g/pot) } \\
\cline { 2 - 5 } & CK & 25 & 50 & 75 \\
\hline Zeolite & 7.786 & 7.883 & 7.874 & 7.872 \\
\hline Bentonite & 7.786 & 7.955 & 7.898 & 7.898 \\
\hline AC & 7.786 & 7.987 & 7.896 & 7.912 \\
\hline CS-Zeolite & 7.786 & 7.793 & 7.925 & 7.835 \\
\hline CS-Bentonite & 7.786 & 7.788 & 7.937 & 7.923 \\
\hline CS-AC & 7.786 & 7.909 & & \\
\hline
\end{tabular}

with increasing soil $\mathrm{pH}$. Zeolite, bentonite, $\mathrm{AC}$, and their chitosan composites showed an alkaline $\mathrm{pH}$; their application significantly affected soil $\mathrm{pH}$. This, in turn, can reduce the biological effectiveness of heavy metals to a certain extent. Besides, soil has intrinsic buffer properties and the $\mathrm{pH}$ therefore remained alkaline.

\section{Effects of Different Amendments} on the Dry Weight of Brassica juncea

The impacts of different amendments on the dry weight of individual Brassica juncea plants are shown in Table 4, along with the ANOVA results. The results showed that the addition of the amendments significantly increased the dry weight of individual Brassica juncea plants. However, there were no significant differences between the different pots in the same dosage. Plant dry weight increased with increasing amendment dosage ( $25 \mathrm{~g}, 50 \mathrm{~g}$, and $75 \mathrm{~g})$. The highest increase in dry weight was observed with the addition of CS-AC, followed by CS-bentonite, CS-zeolite, AC, bentonite, and zeolite. With an amendment dose of $75 \mathrm{~g}$ per pot, individual Brassica juncea dry weight increased by $41.91 \%, 39.00 \%, 27.64 \%, 35.93 \%, 23.78 \%$, and $23.58 \%$ for CS-AC, CS-bentonite, CS-zeolite, AC, bentonite, and zeolite, respectively, compared with the control.

Cadmium contamination can significantly reduce soil $\mathrm{pH}$, negatively impacting crop growth and development. The addition of different soil amendments can improve soil $\mathrm{pH}$ and growth conditions, thereby decreasing soil $\mathrm{Cd}$ activity. Therefore, the adverse soil conditions to the growth and development of Brassica juncea can be alleviated, abating the negative impacts of excessive soil cadmium. This may explain the higher dry weight values for individual Brassica juncea in treatments with added amendments compare to control. The higher dry weights in chitosan composite-treated soils might be attributed to the introduced chitosan and increased soil $\mathrm{pH}$ [40]. One reason is that chitosan has a large amount of amino and hydroxyl groups with a high affinity for $\mathrm{Cd}$ ions, making it highly suitable for Cd removal [20, 41-43]. The Brassica juncea dry weight in chitosan composite-treated soil was higher than in soil with other amendments; these results are agreement with the findings of Shaheen et al. [40]. So the addition of different amendments had beneficial effects on the growth of Brassica juncea because all treatments with amendments had a higher dry weight than the control.

\section{Effects of Different Amendments on Cd Uptake by Brassica juncea}

Table 5 shows the effects of different amendments on Cd uptake by Brassica juncea and the ANOVA results. Cadmium uptake was significantly decreased, albeit to different degrees, with the addition of various amendments. Different dosages resulted in significant differences in terms of $\mathrm{Cd}$ uptake by Brassica juncea.

Table 4. Brassica juncea dry weight in soils treated with different amendments.

\begin{tabular}{|c|c|c|c|c|}
\hline \multirow{2}{*}{ Amendment } & \multicolumn{4}{|c|}{ Dry weight of individual Breassica jincea $(\mathrm{g})$} \\
\cline { 2 - 5 } & $0(\mathrm{~g} / \mathrm{pot})$ & $25(\mathrm{~g} / \mathrm{pot})$ & $50(\mathrm{~g} / \mathrm{pot})$ & $75(\mathrm{~g} / \mathrm{pot})$ \\
\hline Zeolite & $8.058 \pm 0.41 \mathrm{Ab}$ & $9.381 \pm 0.62 \mathrm{Aa}$ & $9.669 \pm 0.57 \mathrm{Aa}$ & $9.958 \pm 0.25 \mathrm{Aa}$ \\
\hline Bentonite & $8.058 \pm 0.41 \mathrm{Ab}$ & $9.513 \pm 0.43 \mathrm{Aa}$ & $9.894 \pm 0.88 \mathrm{Aa}$ & $9.974 \pm 0.53 \mathrm{Aa}$ \\
\hline AC & $8.058 \pm 0.41 \mathrm{Ab}$ & $9.611 \pm 0.58 \mathrm{Aab}$ & $10.545 \pm 0.45 \mathrm{Aa}$ & $10.953 \pm 1.45 \mathrm{Aa}$ \\
\hline CS-zeolite & $8.058 \pm 0.41 \mathrm{Ab}$ & $9.582 \pm 0.31 \mathrm{Aa}$ & $9.913 \pm 0.54 \mathrm{Aa}$ & $10.285 \pm 0.34 \mathrm{Aa}$ \\
\hline CS-bentonite & $8.058 \pm 0.41 \mathrm{Ac}$ & $9.681 \pm 0.38 \mathrm{Ab}$ & $10.331 \pm 0.38 \mathrm{Ab}$ & $11.201 \pm 0.19 \mathrm{Aa}$ \\
\hline CS-AC & $8.058 \pm 0.41 \mathrm{Ac}$ & $9.806 \pm 0.41 \mathrm{Ab}$ & $11.367 \pm 0.79 \mathrm{Aa}$ & $11.435 \pm 0.40 \mathrm{Aa}$ \\
\hline
\end{tabular}


Table 5. Cd content of plants in soil treated with different amendments.

\begin{tabular}{|c|c|c|c|c|}
\hline \multirow{2}{*}{ Amendments } & \multicolumn{4}{|c|}{ The Cd content $(\mathrm{mg} / \mathrm{kg})$} \\
\cline { 2 - 5 } & $0(\mathrm{~g} / \mathrm{pot})$ & $25(\mathrm{~g} / \mathrm{pot})$ & $50(\mathrm{~g} / \mathrm{pot})$ & $75(\mathrm{~g} / \mathrm{pot})$ \\
\hline Zeolite & $4.98 \pm 0.15 \mathrm{Aa}$ & $4.45 \pm 0.06 \mathrm{Ab}$ & $4.31 \pm 0.09 \mathrm{Ab}$ & $4.29 \pm 0.04 \mathrm{Ab}$ \\
\hline Bentonite & $4.98 \pm 0.15 \mathrm{Aa}$ & $4.33 \pm 0.07 \mathrm{ABCb}$ & $4.24 \pm 0.11 \mathrm{ABb}$ & $4.11 \pm 0.11 \mathrm{ABb}$ \\
\hline AC & $4.98 \pm 0.15 \mathrm{Aa}$ & $4.38 \pm 0.06 \mathrm{ABb}$ & $4.17 \pm 0.07 \mathrm{ABb}$ & $4.05 \pm 0.14 \mathrm{BCb}$ \\
\hline CS-Zeolite & $4.98 \pm 0.15 \mathrm{Aa}$ & $4.38 \pm 0.06 \mathrm{ABb}$ & $4.12 \pm 0.16 \mathrm{ABb}$ & $4.01 \pm 0.15 \mathrm{BCb}$ \\
\hline CS-Bentonite & $4.98 \pm 0.15 \mathrm{Aa}$ & $4.28 \pm 0.09 \mathrm{BCb}$ & $4.07 \pm 0.06 \mathrm{BCb}$ & $3.99 \pm 0.15 \mathrm{BCb}$ \\
\hline CS-AC & $4.98 \pm 0.15 \mathrm{Aa}$ & $4.23 \pm 0.10 \mathrm{Cb}$ & $3.91 \pm 0.13 \mathrm{Cb}$ & $3.89 \pm 0.10 \mathrm{Cb}$ \\
\hline
\end{tabular}
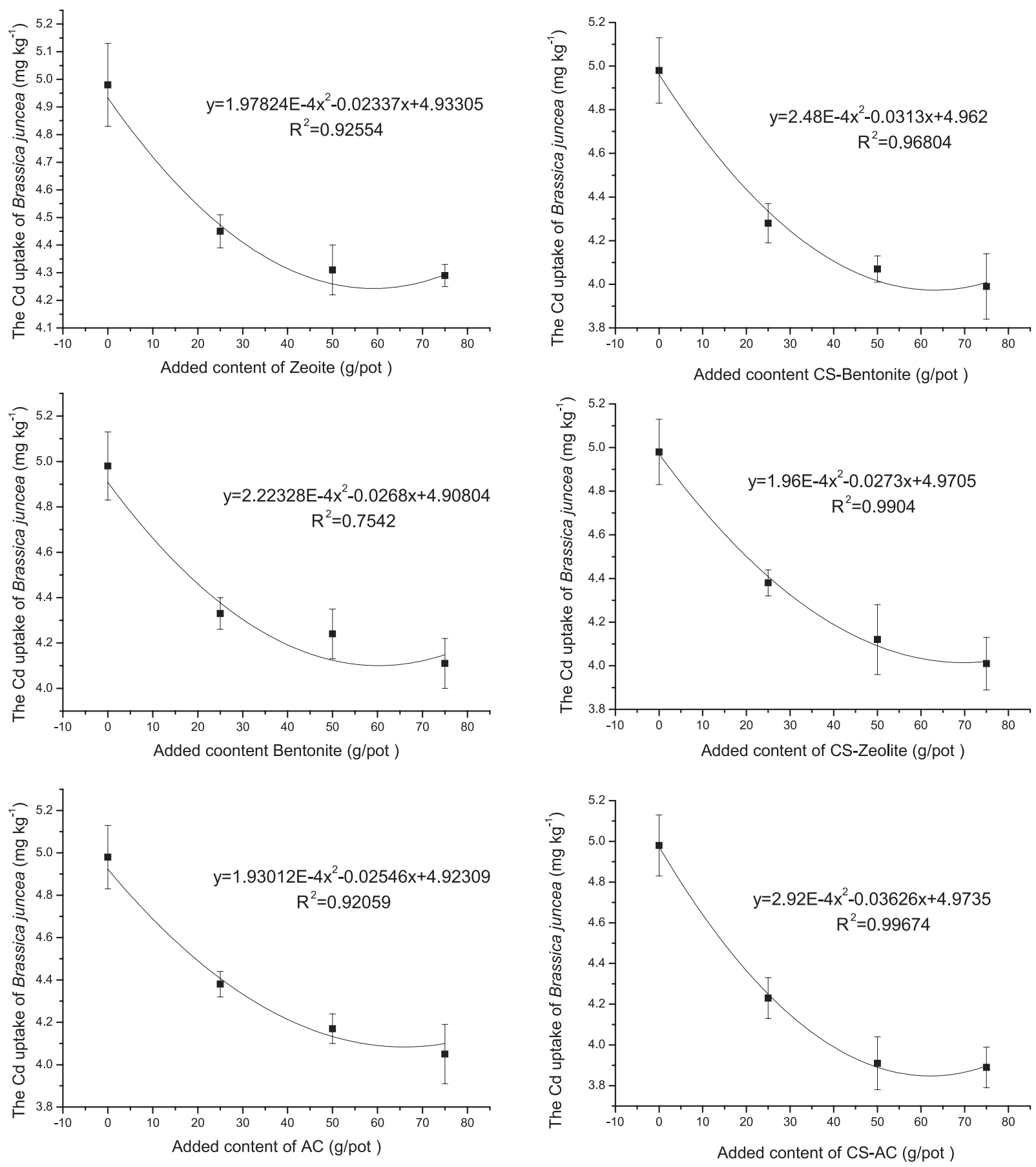

Fig. 1. Regression curves between Cd uptake by Brassica juncea and added amount of different soil amendments. 
The lower the content of $\mathrm{Cd}$ in Brassica juncea, the better the effect of the amendment-fixed $\mathrm{Cd}$. The highest effects were found for CS-AC, followed by CSbentonite, CS-zeolite, AC, bentonite, and zeolite, which means that the effect of the fixed $\mathrm{Cd}$ of the amendments was followed by CS-AC, CS-bentonite, CS-zeolite, $\mathrm{AC}$, bentonite, and zeolite. The effect of dosage on $\mathrm{Cd}$ uptake was also studied for various amendment dosages (25 g, $50 \mathrm{~g}$, and $75 \mathrm{~g}$ ). With a dosage of $75 \mathrm{~g}$ per pot, the Cd uptake by Brassica juncea was lower than the other dosages. Cadmium uptake decreased by $21.89 \%, 19.88 \%, 19.48 \%, 18.67 \%, 17.47 \%$, and $13.85 \%$, respectively, for CS-AC, CS-bentonite, CS-zeolite, AC, bentonite, and zeolite. The results clearly show that remediation efficiency was better than the treatments without added chitosan, most likely due to the addition of chitosan with a large number of adsorption sites. Chitosan contain large numbers of chemical groups, such as amine and hydroxyl groups, and these groups have the ability to bind the $\mathrm{Cd}$ metals through several mechanisms, including chemical interactions such as chelation, electrostatic interactions, such as ion exchange, or the formation of ion pairs [44]. Besides, the effect of amendments on Cd uptake by Brassica juncea was $\mathrm{CS}>$ bentonite $>$ zeolite. It may be that the AC itself has a larger surface area and stronger adsorption capacity than other two materials. The relative percentage of $\mathrm{Cd}$ desorbed from bentonite was higher than from zeolite. This means that bentonite has a stronger and more specific bonding of $\mathrm{Cd}$ compared to zeolite. These results may be attributed to the differences in the amendments' characteristics and structures. Although natural zeolite also has good adsorption performance, because the channels of zeolite are often blocked by some impurities and uneven arrangement these faults limit its adsorption effect. Bentonite contains a high proportion of swelling clays [45] and has the tendency to increase in volume (swell) [46] and provide a much higher surface area [28].

In order to understand the effects of different amendments on $\mathrm{Cd}$ uptake by Brassica juncea, regression equations and the corresponding correlation curves were fitted and are shown in Fig. 1 (amendment dosage as independent variable and $\mathrm{Cd}$ uptake as dependent variable)
The relationship between $\mathrm{Cd}$ uptake and the addition of different amendments followed a reverse "parabola"type function (Fig. 1). Correlation coefficient $\left(\mathrm{R}^{2}>0.92\right)$ of samples treated with chitosan was higher than that in samples without chitosan. With an amendment dosage of 50-75 g per pot, Cd uptake was the correspondingly lowest. Hence 50-75 g/pot amendments can be used for preliminary dosage to repair Cd-polluted soil. To sum up, the dosage of various amendments treated with Cd-polluted soil is appropriate for 50-75 g/pot. The amendment can reduce by $14 \%$ the $\mathrm{Cd}$ uptake by Brassica juncea at least. In this case, CS-AC has the greatest potential for reducing $\mathrm{Cd}$ uptake by Brassica juncea.

\section{Effects of Different Amendments on Bioavailable Cd Content}

According to the ANOVA results (Table 6), the addition of different amendments significantly decreased bioavailable $\mathrm{Cd}$ content compared to the control. Differences were also found between the different amendment dosages. And the results show that the bioavailable $\mathrm{Cd}$ content has a different degreereducing effect treated with different amendments. In other words, all six kinds of amendments on the heavy metal $\mathrm{Cd}$ have a certain fixed effect. With a dosage of $75 \mathrm{~g}$ CS-AC per pot, bioavailable Cd content was lowest and significantly decreased by $27.38 \%$ compared to the control. Based on the results of multiple comparisons, adding $25 \mathrm{~g}$ and $50 \mathrm{~g}$ of CS-AC per pot did not result in a significant difference in terms of bioavailable $\mathrm{Cd}$ content. With a dosage of $75 \mathrm{~g}, 50 \mathrm{~g}, 75 \mathrm{~g}, 75 \mathrm{~g}, 50 \mathrm{~g}$, and $75 \mathrm{~g}$ per pot for CS-AC, CS-bentonite, CS-zeolite, $\mathrm{AC}$, bentonite, and zeolite, respectively, bioavailable Cd content decreased by $27.38 \%, 19.29 \%, 22.83 \%$, $23.22 \%, 15.74 \%$, and $8.66 \%$, respectively, compared to the control. Bioavailable $\mathrm{Cd}$ content was higher in treatments with the addition of chitosan compared to treatments without chitosan (Table 6), which has a large number of active sites and, consequently, a high affinity for $\mathrm{Cd}$ ions. On the other hand, activated carbon has a lager surface area and a strong adsorption capacity. The effectiveness of heavy metals was decreased through the following two effects: 1) The metals are directly adsorbed by activated carbon and 2) The addition

Table 6. Contents of bioavailable in soil treated with different amendments.

\begin{tabular}{|c|c|c|c|c|}
\hline \multirow{2}{*}{ Amendments } & \multicolumn{4}{|c|}{ The bioavailable Cd content $(\mathrm{mg} / \mathrm{kg})$} \\
\cline { 2 - 5 } & 0 & 25 & 50 & $\mathbf{7 5}$ \\
\hline Zeolite & $2.54 \pm 0.07 \mathrm{Aa}$ & $2.46 \pm 0.09 \mathrm{Aa}$ & $2.38 \pm 0.04 \mathrm{Ab}$ & $\mathbf{2 . 3 2} \pm \mathbf{0 . 1 0} \mathrm{Ab}$ \\
\hline Bentonite & $2.54 \pm 0.07 \mathrm{Aa}$ & $2.21 \pm 0.05 \mathrm{Bb}$ & $\mathbf{2 . 1 4} \pm \mathbf{0 . 1 2} \mathrm{Bb}$ & $2.16 \pm 0.14 \mathrm{Ab}$ \\
\hline AC & $2.54 \pm 0.07 \mathrm{Aa}$ & $2.28 \pm 0.10 \mathrm{Bb}$ & $2.11 \pm 0.07 \mathrm{Bc}$ & $\mathbf{1 . 9 5} \pm \mathbf{0 . 1 0} \mathrm{Bc}$ \\
\hline CS-Zeolite & $2.54 \pm 0.07 \mathrm{Aa}$ & $2.15 \pm 0.09 \mathrm{Bb}$ & $2.19 \pm 0.11 \mathrm{Bb}$ & $\mathbf{1 . 9 6} \pm \mathbf{0 . 0 9} \mathrm{Bc}$ \\
\hline CS-Bentonite & $2.54 \pm 0.07 \mathrm{Aa}$ & $2.13 \pm 0.09 \mathrm{Bb}$ & $\mathbf{2 . 0 5} \pm \mathbf{0 . 1 1 B b}$ & $2.08 \pm 0.09 \mathrm{ABb}$ \\
\hline CS-AC & $2.54 \pm 0.07 \mathrm{Aa}$ & $2.03 \pm 0.11 \mathrm{BCb}$ & $2.01 \pm 0.10 \mathrm{BCbc}$ & $\mathbf{1 . 8 5} \pm \mathbf{0 . 0 8 B C c}$ \\
\hline
\end{tabular}


of activated carbon can increase the content of soil organic carbon, thereby indirectly increasing heavy metal fixation [47]. Based on the above-described results, adding chitosan as a soil amendment results in a significant reduction of bioavailable $\mathrm{Cd}$.

\section{Conclusion}

We investigated changes in soil $\mathrm{pH}$, Brassica juncea dry weight, Cd content of Brassica juncea, and available soil $\mathrm{Cd}$ content with the addition of natural and chitosanintroduced zeolite, bentonite, and activated carbon. Our results show that natural and chitosan-introduced zeolite and bentonite can increase soil $\mathrm{pH}$ and reduce the biological effectiveness of heavy metals to a certain extent. Although activated carbon has an acidic $\mathrm{pH}$ value, the soil could buffer this effect and stay alkaline. With increasing amendment dosage, Brassica juncea dry weight increased. With an amendment dosage of $75 \mathrm{~g}$ per pot, Cd uptake by Brassica juncea was lowest. With a dosage of $75 \mathrm{~g}, 50 \mathrm{~g}, 75 \mathrm{~g}, 75 \mathrm{~g}, 50 \mathrm{~g}$, and $75 \mathrm{~g}$ per pot for CS-AC, CS-bentonite, CS-zeolite, AC, bentonite, and zeolite, respectively, $\mathrm{Cd}$ uptake decreased by $21.89 \%, 19.88 \%, 19.48 \%, 18.67 \%, 17.47 \%$, and $13.85 \%$, respectively. Similarly, bioavailable Cd content decreased by $27.38 \%, 19.29 \%, 22.83 \%, 23.22 \%, 15.74 \%$, and $8.66 \%$, respectively, compared to the control.

The results of this study are of considerable significance in demonstrating the practical application of chitosan in the successful remediation of Cd-contaminated soil.

\section{Acknowledgements}

The authors gratefully acknowledge financial support by the Ministry of Agriculture of the People's Republic of China (No. 201203045), the Seed Foundation of Innovation and Creation for Graduate Students in Northwestern Polytechnic University (Z2017192), the National Natural Science Foundation of China (41502240), the Natural Science Basic Research Plan in Shaanxi Province of China (2017JM4005), the Fundamental Research Funds for the Central Universities (3102017zy056), and the Key Laboratory of Groundwater Contamination and Remediation, China Geological Survey (CGS) and Hebei Province (KF201610).

\section{Conflict of Interest}

The authors declare no conflict of interest.

\section{References}

1. BASZYNSSKI T. Interference of $\mathrm{Cd}^{2+}$ in functioning of the photosynthetic apparatus of higher plants. Acta Societatis Botanicorum Poloniae, 55 (2), 291, 1986.
2. HE H., NORA F.Y.T., YAO A, QIU R., LI, W.C., YE Z. Growth and Cd uptake by rice (Oryza sativa) in acidic and Cd-contaminated paddy soils amended with steel slag. Chemosphere, 189, 247, 2017.

3. VAREDA J.P., VALENTE A.J.M., DURÃES L. Heavy metals in Iberian soils: Removal by current adsorbents/ amendments and prospective for aerogels. Advances in Colloid and Interface Science, 237, 28, 2016.

4. MAHAR A., WANG P., ALI A., GUO Z.Y., AWASTHI M.K., LAHORI A.H., WANG Q., SHEN F., LI R.H., ZHANG Z.Q. Impact of $\mathrm{CaO}$, fly ash, sulfur and $\mathrm{Na}_{2} \mathrm{~S}$ on the (im)mobilization and phytoavailability of $\mathrm{Cd}, \mathrm{Cu}$ and $\mathrm{Pb}$ in contaminated soil. Ecotoxicology and Environmental Safety, 134, 116, 2016.

5. ALI A., GUE D., MAHAR A., WANG P., SHEN F., LI R.H., ZHANG Z. Mycoremediation of potentially toxic trace elements- a biological tool for soil cleanup: a review. Pedosphere, 27 (2), 205, 2017.

6. TICA D., UDOVIC M., LESTAN D. Immobilization of potentially toxic metals using different soil amendments. Chemosphere, 85( 4) 577, 2011.

7. PÉREZ-ESTEBAN J., ESCOLÁSTICO C., MOLINER A., MASAGUER A., RUIZ-FERNÁNDEZ J. Phytostabilization of metals in mine soils using Brassica juncea in combination with organic amendments. Plant and Soil, 377 (1-2), 97, 2014.

8. HUSSAIN L.A., ZHANG Z., GUO Z., MAHAR A., LI R., KUMAR A.M., ALI S.T., KUMBHAR F., WANG P., SHEN F., ZHAO J., HUANG H. Potential use of lime combined with additives on (im)mobilization and phytoavailability of heavy metals from $\mathrm{Pb} / \mathrm{Zn}$ smelter contaminated soils. Ecotoxicology and Environmental Safety, 145, 313, 2017.

9. RAFIQ M.T., AZIZ R., YANG X., XIAO W., RAFIQ M.K., ALI B., LI T. Cadmium phytoavailability to rice (Oryza sativa L.) grown in representative Chinese soils. A model to improve soil environmental quality guidelines for food safety. Ecotoxicology and Environmental Safety, 103 (1), 101, 2014.

10. LI G., QIU J., YIN C. Study on calculating losses of cropland degradation. Chinese Agricultural Science Bulletin, 25 (3), 230, 2009.

11. YAN H., LIN G. Usage of chitosan on the complexation of heavy metal contents and vertical distribution of $\mathrm{Hg}$ (II) and $\mathrm{Cr}$ (VI) in different textural artificially contaminated soils. Environmental Earth Sciences, 73 (5), 2483, 2015.

12. GONZÁLEZ-NÚÑEZ R., ALBA M.D., ORTA M.M., VIDAL M., RIGOL A. Remediation of metalcontaminated soils with the addition of materials - Part I: Characterization and viability studies for the selection of non-hazardous waste materials and silicates. Chemosphere, 85 (9), 1511, 2011.

13. SHAHEEN S.M., TSADILAS C.D., RINKLEBE J. 2015. Immobilization of soil copper using organic and inorganic amendments. Journal of plant nutrition and soil science, 178 (1), 112, 2015.

14. GONZÁLEZ-NÚÑEZ R., ALBA M.D., ORTA M.M., VIDAL M., RIGOL A. Remediation of metalcontaminated soils with the addition of materials - Part II: Leaching tests to evaluate the efficiency of materials in the remediation of contaminated soils. Chemosphere, 87 (8), 829, 2012.

15. HUANG R., YANG B., LIU Y. Simultaneous adsorption of aniline and $\mathrm{Cr}$ (VI) ion by activated carbon/chitosan composite. Journal of applied polymer, 131 (4), 1, 2014. 
16. CRINI G. Recent developments in polysaccharide-based materials used as adsorbents in wastewater treatment. Progress of Polymer Science, 30 (1), 38, 2005.

17. TRIPATHI N., CHOPPALA G., SINGH R.S. Evaluation of modified chitosan for remediation of zinc contaminated soils. Journal of Geochemical Exploration http//dx.doi. org/10.1016/j.gexplo.2016.08.011, 2016

18. ZHANG L., ZENG Y.X., CHENG Z.J. Removal of heavy metal ions using chitosan and modified chitosan: A review. Journal of Molecular Liquids, 214, 175, 2016.

19. MUZZARELLI R.A.A. Industrial Production and Application. Chitin, Pergamon Press, Oxford, England, 207, 1977.

20. LI M., ZHANG Z., LI R., WANG J., ALI A. Removal of $\mathrm{Pb}$ (II) and $\mathrm{Cd}$ (II) ions from aqueous solution by thiosemicarbazide modified chitosan. International Journal of Biological Macromolecules, 86, 876, 2016.

21. BORNET A., TEISSEDRE P.L. Chitosan, chitin-glucan and chitin effects on minerals (iron, lead, cadmium) and organic (ochratoxin A) contaminants in wines. European Food Research and Technology, 226 (4), 681, 2008.

22. XU Y., LIANG X.F., QIN X., HUANG Q.Q., WANG L., SUN Y.B. Remediation of heavy metal-polluted agricultural soils using clay minerals: A review. Pedosphere, 27 (2), 193, 2017.

23. SUN Y., Wu Q.T., LEE C.C.C., LI B.Q., LONG X.X. Cadmium sorption characteristics of soil amendments and its relationship with the cadmium uptake by hyperaccumulator and normal plants in amended soils. International Journal of Phytoremediation, 16 (5), 486, 2014.

24. FU F., WANG Q. Removal of heavy metals from wastewaters: a review. Journal of Environmental Management, 92, 407, 2011.

25. KUMARARAJA P., MANJAIAH K.M., DATTA S.C., SARKAR B. Remediation of metal contaminated soil by aluminium pillared bentonite: Synthesis, characterisation, equilibrium study and plant growth experiment. Applied Clay Science, 137, 115, 2017.

26. LI P., AN Z., ZHAO T., LIU B., ZHANG C., ZHANG J., YANG M., ZHANG D., LI Y. Effects of natural zeolite addition on $\mathrm{Cd}$ in soil and tamato biomass. Ecology and Environmental Sciences, 20 (6-7), 1147, 2011.

27. LIU X., ZHAO X., MA Z. Application of bentonite and zeolite in dealing soil contaminated by Cd. Journal of Soil and Water Conservation, 21 (6), 83, 2007.

28. HAMIDPOUR M., KALBASI M., AFYUNI M., SHARIATMADARI H., HOLM P., HANSEN G. Sorption hysteresis of $\mathrm{Cd}$ (II) and $\mathrm{Pb}$ (II) on natural zeolite and bentonite. Journal of Hazardous of Materials, 181 (1-3), 686, 2010.

29. SUN Y., LI Y., XU Y., LIANG X., WANG L. In situ stabilization remediation of cadmium $(\mathrm{Cd})$ and lead $(\mathrm{Pb})$ co-contaminated paddy soil using bentonite. Appled Clay Science, 105-106, 200, 2015.

30. LI J., LI Y., MENG Q. Removal of nitrate by zerovalent iron and pillared bentonite. Journal of Hazardous Materials, 174 (1-3), 188, 2010.

31. BŘENDOVÁ K., ZEMANOVÁ V., PAVLÍKOVÁ D., TLUSTOŠ P. Utilization of biochar and activated carbon to reduce $\mathrm{Cd}, \mathrm{Pb}$ and $\mathrm{Zn}$ phytoavailability and phytotoxicity for plants. Journal of Environmental Management, 181, 637, 2016.

32. EBBS S.D., LASAT M.M., BRADY D.J., CORNISH J., GORDON R., KOCHIAN L.V. Phytoextraction of cadmium and zinc from a contaminated soil. Journal of Environmental Quality, 26 (5), 1424, 1997.

33. EBBS S.D., KOCHIAN L.V. Phytoextraction of Zinc by oat (Avena sativa), barley (Hordeum vulgare), and Indian mustard (Brassica juncea). Environmental Science and Technology, 32 (6), 802, 1998.

34. CHEN H., ZHENG C., TU C., SHEN Z. Chemical ethods and phytoremediation on soil contaminated with heavy metals. Chemosphere, 41 (1-2), 229, 2000.

35. TRIPATHI R.D., VAJPAYEE P., SINGH N., RAI U.N., KUMAR A., ALI M.B., KUMAR B., YUNUS M. Efficacy of various amendments for amelioration of flyash toxicity: growth performance and metal composition of Cassiasiamea Lamk. Chemosphere, 54 (11), 1581, 2004.

36. JI P., SUN T., SONG Y., ACKLAND M.L., LIU Y. Strategies for enhancing the phytoremediation of cadmium-contaminated agricultural soils by Solanum nigrum L. Environmental Pollution, 159 (3), 762, 2011.

37. ZHANG Q., LI J., XU M., SONG Z., ZHOU S. Effect of amendments on bioavailability of cadmium and zinc in compound contaminated red soil. Journal of AgroEnvironment Science, 25 (4), 861, 2006.

38. BOLAN N.S., CHOPPALA G., KUNHIKRISHNAN A., PARK J., NAIDU R. Microbial transformation of trace elements in soils in relation to bioavailability and remediation. Reviews of Environmental Contamination and Toxicology. 225, 1, 2013.

39. YANG L., CHEN Z., LIU Y., WANG Y. Effects of lime and activated carbon on remedying chromium contaminated soil. Acta Pedologica Sinica, 49 (3), 518, 2012.

40. SHAHEEN S., RINKLEBE J. Impact of emerging and low cost alternative amendments on the (im)mobilization and phytoavailability of $\mathrm{Cd}$ and $\mathrm{Pb}$ in a contaminated floodplain soil. Ecological Engineering, 74 (1), 319, 2015.

41. GUO Z., HU X., AO Y. Effect of chitosan on the available contents and vertical distribution of $\mathrm{Cu}^{2+}$ and $\mathrm{Cd}^{2+}$ in different textural soils. Journal of Hazardous Materials, 167 (1-3), 1148, 2009.

42. BORSAGLI F.G.L.M., MANSUR A.A.P., CHAGAS P., OLIVERIRA L.C.A., MANSUR H.S. O-carboxymethyl functionalization of chitosan: Complexation and adsorption of Cd (II) and Cr (VI) as heavy metal pollutant ions. Reactive and Functional Polymers, 97, 37, 2015.

43. ZENG L., CHEN Y., ZHANG Q., GUO X., PENG Y., XIAO H., CHEN X., LUO J. Adsorption of Cd (II), Cu(II) and $\mathrm{Ni}(\mathrm{II})$ ions by cross-linking chitosan/rectoritenanohybrid composite microspheres. Carbohydrate Polymers, 130, 333, 2015.

44. EROSA M.S.D., EROSA T.I.S., MEDINA R.N., MENDOZA M.A., RODRIGUEZ, GUIBAL E. Cadmium sorption on chitosan sorbents: kinetic and equilibrium studies. Hydrometallurgy, 61 (3), 407, 2011.

45. NGAH W.S.W., TEONG L.C., HANAFIAH M.A.K.M. Adsorption of dye and heavy metal ions by chitosan composite: A review. Carbohydrate Polymers, 83 (4), 1446, 2011.

46. KAYA A., ÖREN A.H. Adsorption of zinc from aqueous solutions to bentonite. Journal of Hazardous of Materials, 125 (1-3), 183, 2005

47. HU Z., ZHANG G., WANG G., ZHAO Q., LIU X., CAO $X$., CAO Z. Effect of soil amendments on cadmium and lead contents in tobacco. Acta Pedologica Sinica, 43 (2), 233, 2006. 